University of Rhode Island

DigitalCommons@URI

Open Access Master's Theses

1970

\title{
Enzymatic Hydrolosis of 16s Ribosomal RNA and 30s Ribosomal Subunits
}

Jaime Amaya-Farfan

University of Rhode Island

Follow this and additional works at: https://digitalcommons.uri.edu/theses

\section{Recommended Citation}

Amaya-Farfan, Jaime, "Enzymatic Hydrolosis of 16s Ribosomal RNA and 30s Ribosomal Subunits" (1970). Open Access Master's Theses. Paper 1149.

https://digitalcommons.uri.edu/theses/1149

This Thesis is brought to you for free and open access by DigitalCommons@URI. It has been accepted for inclusion in Open Access Master's Theses by an authorized administrator of DigitalCommons@URI. For more information, please contact digitalcommons-group@uri.edu. 
QH603

R5

A52

ENZYMATIC HYDROLYSIS OF I6S RIBOSOMAL RNA

AND 30S RIBOSOMAL SUBUNITS

BY

JATME AMAYA-FARFAN

A THESIS SUBMITIED IN PARTIAL FULFILLMENT OF THE

REQUIREMENTS FOR THE DEGREE OF

MASTER OF SCIENCE

IN

BIOLOGICAL SCIENCES

UNIVERSITY OF RHODE ISLAIND

1970 
MASTER OF SCIENCE THESIS

$\mathrm{OF}$

JAIME AMAYA-FARFAN

Approved :

Thesis Committee:

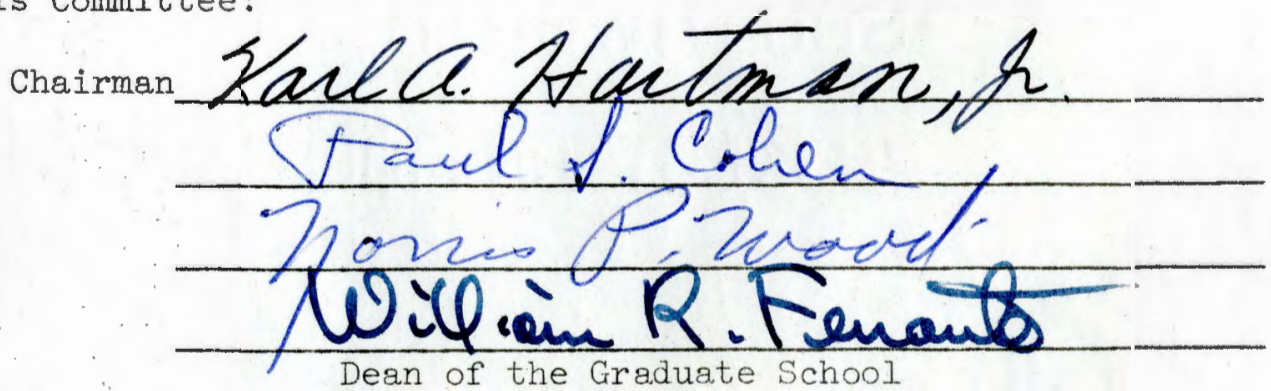

University of Rhode Island 


\section{ABSTRACT}

E. coli $30 \mathrm{~S}$ ribosomal subunits and protein-free 16S RNA have been milaly hydrolyzed with pancreatic ribonuclease and the RNA fragments analyzed by polyacrylamide gel electrophoresis. The protein-free RNA gives nine discrete fragments and the 30 s subunits give six discrete fragments. A comparison of electrophoretic mobilities, indicates that at least three fragments from 16S RNA are distinct from the fragments from 30s. The kinetics of the hydrolysis reaction is pseudo first-order for the protein-free 16S RNA and pseudo secondorder for the $30 \mathrm{~s}$ ribosomes. The rate of hydrolysis of the proteinfree 16S RNA is much faster than that of the $30 \mathrm{~S}$ subunit. These data suggest that in the protein-free 16S RNA there are certain regions exposed to the ribonuclease which are not exposed in the ribosome, and that this is due to either some shielding by the specific proteins or to a different conformation of the RNA in the ribosome. 


\section{ACKNOWLEDGMENTS}

I am grateful to Dr. Karl A. Hartman, advisor and chairman of the thesis committee, for his constant guidance and support throughout this research. I am also indebted to Dr. Eugene M. Schachter for his invaluable experience with the polyacrylamide gel technique and his enlightening discussions on this work. Thanks are due also to Dr. Paul S. Cohen for his suggestions and corrections during the preparation of the manuscript.

Throughout this research the author was partly supported by a fellowship from the Latin American Scholarship Program of American Universities in Cambridge, Mass. 


\section{TO MARY}

who would rather not look at "those moving slimy gels." 


\section{ABSTRACT}

IITRODUCTION

Albosomal ribonucleic acid, rRNA, is a component of ribosomes

rRNA appears to have certain secondary and tertiary structures I

Evidence for a secondary structure from infrared studies 2

Ion binding studies correlated with the organization of ribosomes

$X$-ray diffraction studies applied to the conformation of rRNA

Hypochromicity measurements on the conformation of rRNA

Optical rotatory dispersion applied to the conformation of rRINA

The use of the enzyme pRNase to detect a tertiary structure of rRINA

Definition and approach of present work

Objectives of this work

\section{EXPERIMENTAL}

Growth of the bacteria

Preparation of the ribosomes

Preparation of the 16S RNA

The pancreatic ribonuclease

Thebydrolysis of RNA and ribosomes

The polyacrylamide gels

Eactrophoresis of the RNA 
RESUTTS

Mild hydrolysis of protein-free 16S rRNA generates nine discrete fragments

Mild byrolysis of 30 s subunits generates six discrete RNA fragments

Notable differences between figure 1 and 2

Pseudo first-order rate constant for 165 rRNA

Pseudo second-order rate constants for 3 as subunits

Resistance of 30 subunits to hydrolysis

DISCUSSION

The resulting discrete fragments from the hydrolysis of proteinfree 16s rRNA suggests that it has a tertiary structure.

Fossible mechanism for the onset of the hydrolysis reaction of protein-free $16 \mathrm{~S}$ rRNA

RNA fragment pattern of $30 \mathrm{~S}$ subunit suggests that there is a definite ribosomal conformation

Comparison between the fragment patterns of protein-free RNA and 30 s subunits

Possible mechanism for the hydrolysis reaction of 30 s subunits

The 30 s subunit is mostly protected from the action of the RNase

The conformation of protein-free $16 \mathrm{~S}$ rRNA is not necessarily

the same of rRNA in the ribosome

FIGURES AND TABLES

Figure la, c, and d Stages of mild hydrolysis of 165 rRNA

Figure 1b

Fragment pattern for protein-free $16 \mathrm{~S}$ rRNA

Table 1

Molecular weights for fragments of figure 1

Figure 2

Fragment pattern for 30 s subunits

Table 2 
Figure 3a Kinetic plots for hydrolysis of 1:6S rRNA 26

Figure 3b- Resistance of 30s rịbosomes $\quad 27$

Figure 4a Zeroth-order: $\begin{aligned} & \text { kinetic plot for hydrolysis of } 30 \mathrm{~S} \\ & \text { subunits }\end{aligned}$

Figure 4b. First-order: $\begin{aligned} & \text { kinetic plot for hydrolysis of } 305 \\ & \text { subunits }\end{aligned}$

Figure 4c second-order: kinetic plot for hydrolysis of 305 subunits 30

REFFRENCES

APPENDIX

Apparent dependence of the fragment patterns on monovalent cations (two figures) 


\section{INTRODUCTION}

Ribosomes are cytoplasmic organelles whose function is the Mosynthesis of proteins. In the case of the bacterium Escherichia coli, they are composed of 63 percent ribosomal ribonucleic acid (rRNA ${ }^{*}$ ) and 37 percent of specific ribosomal protein. The physical and functional unit, the $70 S$ ribosome, is formed from the association of a 505 and a 30 s subunit. The 50 s subunit is, in turn, made up of two rRNA components (23S and 5S RNA) plus some 36 specific proteins, while the 30 s subunit consists of a 16S RNA component and some 20 specific proteins. Efforts to elucidate the spatial arrangement of the protein molecules and the conformation (secondary and tertiary structures) of the RINA in each subunit have not yet provided a model of the ribosome.

Previous work suggests that protein-free 235 and 165 RNA in squeous solution have a secondary and a tertiary structure, and that the secondary structure consists of helical "hairpin-like" regions where the bases are paired in a Watson-Crick fashion (1). A fundamental question in studying the structure of the ribosome is whether the conformation of the protein-free RNA is the same as in the ribosome. This problem has been approached with methods such as cation binding,

*Abbreviations employed here are: rRINA is ribosomal ribonucleic acid; $70 S$ is a sedimentation coefficient ( $S$ is the svedberg unit, 10-13 sec.); TMV is Tobacco Mosaic Virus; RNase is a ribonucleolytic enzyme; pRNase is RNase A from bovine pancreas. 
X-ray diffraction, hypochromicity effect, optical rotatory dispersion (ORD), and enzymatic hydrolysis.

By applying Beer-Lambert's law to the infrared spectra of the Individual nucleotides and paired polynucleotides, it has been indicated that yeast rRNA at $30^{\circ} \mathrm{C}$ contains about 60 percent of its bases participating in double helical regions (2).

No detectable difference has been found in the ability to bind $\mathrm{Ca}^{++}$and $\mathrm{Mg}^{++}$between protein-free RNA and ribosomes from $\underline{\mathrm{E}}$. coli as measured by equilibrium dialysis (3). The authors have concluded that $\mathrm{Mg}^{++}$binding only occurs at the phosphate groups, and that all of these groups are available as binding sites for small cations. This conclusion has lead the authors to suggest that the organization of the ribosome must be such that the phosphate groups are not directly involved in the protein-RNA interaction.

Powder patterns from X-ray diffraction studies on isolated rRNA and ribosomes from rat liver, yeast and E. coli are similar and have been taken as an indication that the conformation of the rRNA may be similar in all cases $(4,5)$.

Protein-free rRNA as well as ribosomes from the various sources investigated have been reported to exhibit equally low extinction coefficients at $2600 \mathrm{~A}$ (property known as hypochromism). The fact that the hypochromicities of the isolated rRNA and ribosomes change identically as the RNA is being denatured by heat or by hroloysis has been interpreted by the authors as evidence that the wcondary structure of rRNA does not change significantly after 
removal of the proteins $(6,7,8)$.

It has also been reported that RNA in rabbit reticulocyte rtbosomes give an ORD spectrum similar to that of the rRNA dissociated from the ribosomal proteins. This has lead the authors to suggest that the conformation of rRNA in the ribosome is similar to that in the protein-free state $(9,10)$.

Pancreatic ribonuclease (pRNase) has been used as a probe to torestigate the internal organization of ribosomes. It has been catablished that portions of the rRNA are exposed at the surface of the ribosome instead of being entirely coated by the protein (11) aince the $70 S$ ribosome is hydrolyzable by ribonuclease but to a lesser extent than the isolated rRNA. Using gel electrophoresis, it has been shown that specific cleavage is obtained from unfractionated yeast protein-free rRNA by the action of $\mathrm{T}_{1}$ and pancreatic ribonucleases (12). Likewise, rRNA extracted from purified subunits of rabbit ruticulocyte ribosomes and treated with pRNase has been reported to hydrolyze initially into a number of discrete fragments resolvable by gel electrophoresis (13). The authors have suggested that discrete fragments are produced because certain sites in the RNA are preferentially attacked as a result of a specific folding of the polymer chain into a tertiary structure $(12,13)$.

From the data obtained in previous work, it appears that no conclusive answer can yet be given to the question of whether the Monformation of rRIA changes upon removal of the proteins. The error of the ion binding measurements is too large to clearly show that no 
hosphate bonds are directly involved in protein-RNA interactions. The quality of the $\mathrm{X}$-ray diffraction data is not sufficiently high to even distinguish between heated-and-cooled TMV RNA and a ribosome (4), and therefore the data cannot be used to detect changes in the conformation of the rRNA. The level of hypochromicity is correlated to the mole fraction of paired bases in the structure and is not sensitive to the positions of the short base paired regions. The ORD curve for afferent conformation states of a given polymer is only a function of the average helical content and will not discriminate between two different secondary structures with the same percent of helical content. Therefore these spectroscopic methods, if used together, merely analyze the total helical content of rRNA.

The present work is a comparative study of the pRINase mediated ydrolysis of purified 30 s subunits and of protein-free 16S RNA from E. coli. The factors underlying this enzymatic approach are first, the presence of sites of rRNA which are specifically hydrolyzed by pRNase, and second, the existence of dissimilar rates of hydrolysis depending on individual steric conditions of the substrate.

pRNase at low concentrations is known to exclusively hydrolyze distal to the phosphate group attached to $3^{\prime}$ carbon of the pyrimidine mcleosides in RNA. These residues are assumed to be distributed along the polymer chain as dictated by the primary structure.

It is widely accepted that pRNase principally attacks the aingle regions of RNA. In addition to this selectivity, the access of pRNase to sites in single stranded regions can be hindered by a Aartiary structure of the RNA and the specific or associated proteins 
in the ribosome. Therefore the method used here is a probe for single atranded regions of rRNA with pyrimidine residues which are not ahielded by protein or by the conformation of the RNA.

For these reasons, this technique would allow me to correlate changes in the rate constants of individual sites with changes in their conformation, as opposed to the techniques that have been used to study the changes in conformation by measuring average structural moperties.

Experiments have been designed using mild enzymatic hydrolysis to answer the following questions:

1) Does pRNase hydrolyze protein-free 16S RNA and the RNA in 30 Sibosomes into sets of discrete and specific fragments, and if so, what are the molecular weights of such fragments?

2) What is the order of the reaction kinetics for the rRNA in either state?

3) Is it possible to give a simple mechanism for the early stages of the reactions?

4) Are there any differences between the fragments or the rate constants for the rRNA in either state?

5) Is it possible to detect any conformational differences for the rRNA in either state in this in vitro system? 


\section{EXPERIMENTAL}

1. Growth of the Bacteria

E. coli DlO (RNase $I^{-}$) strain, which were kept and propagated in slant tubes with nutrient agar, were used to make inoculant seed cultures in sterile $1.3 \%$ tryptone medium containing $0.7 \% \mathrm{NaCl}$ and $0.2 \%$ dextrose. The seed cultures were incubated at $37^{\circ} \mathrm{C}$ in a gyratory shaker to a final density of $400-500 \mathrm{Klett}\left(8-10 \times 10^{8}\right.$ cells per milliliter $)$. Large scale exponential cultures were obtained by inoculating 12-liter rolumes of the same medium with the seed cultures to a density of 30 Klett, and then incubating in fermentor at $37^{\circ} \mathrm{C}$ for two or three hours until cells reached a density of 200 Klett $\left(2 \times 10^{8}\right.$ cells $\left./ \mathrm{ml}\right)$. The carboys were then cooled in ice and the cells collected in a Sharples centrifuge.

\section{Preparation of the Ribosomes}

All operations involved in the preparation of the 70S ribosomes and its subunits were carried out at $4^{\circ} \mathrm{C}$. Pellets of cells were ground with an equal weight of alumina using a mortar and pestle. When the mass was smooth and sticky buffer ( $0.01 \mathrm{M} \mathrm{Mg}$ (Acetate) 2 , $0.005 \mathrm{M}$ Tris-Cl $\left(\mathrm{pH} 7.4,0.08 \mathrm{M} \mathrm{NH}_{4} \mathrm{Cl}\right.$ ) was added. The bacterial DNA was then hydrolyzed by making the slurry $5 \mu \mathrm{g} / \mathrm{ml}$ in DNase. The resulting slurry was centrifuged at 22,000g (14,000 rpm in a Sorval preparative centrifuge) for 20 minutes to separate alumina and whole cells from homogenate. After two more low speed 
centrifugations, the 7OS ribosomes were pelleted at $2000,000 \mathrm{~g}(39,000$ rpm in angle-40 rotor of ultracentrifuge Model L) for 150 minutes. The ribosome pellets were resuspended in $0.001 \mathrm{M} \mathrm{Mg}$ (Acetate) 2 , $0.03 \mathrm{M} \mathrm{KCl}$ and $0.005 \mathrm{M} \operatorname{Tris}-\mathrm{Cl}$ ( $\mathrm{pH} 7.4)$.

The 305 subunits were separated from the 50 S subunits by zonal centrifugation using a sucrose gradient of the form developed. by Eikenberry (14), and approximated by means of a constant volume ponential gradient (Eikenberry, personal communication). The detailed procedure of the approximated exponential gradient adapted for the Beckman Ti-14 rotor is as follows. A Mariotte flask with $900 \mathrm{ml}$ of $50 \%$ (w/w) sucrose (Fisher Scientific Co.) feeds a mixing chamber initially containing $295 \mathrm{ml}$ of $7 \%(\mathrm{w} / \mathrm{w})$ sucrose, and whose volume remains constant throughout the loading of the gradient. The gradient is set in the rotor at 3,000 rpm by pumping into it the output of the mixing chamber. When the rotor has been filled, some 300-500 mg of ribosomes previously placed in a linear sucrose gradient ( $1-7 \%$ sucrose in $25 \mathrm{ml}$ volume) are pumped on top of the exponential gradient. An additional volume of $240 \mathrm{ml}$ of buffer is pumped on top of the sample, $40 \mathrm{ml}$ of which are afterward discarded by pumping a $40 \mathrm{ml}$ cushion of the heavy sucrose onto the bottom of the gradient. After 4 hours of centrifugation at 45,000 rpm the 50 s and 30 s particles reached good separation. The speed was then reset at 3,000 rpm, and the gradient unloaded by injecting $600 \mathrm{ml}$ of $50 \%$ sucrose and collected in $10 \mathrm{ml}$ fractions. The absorbance of the fractions was measured at $3000 \mathrm{~A}$. 
The resulting concentration profile facilitates the pooling of the fractions containing $30 \mathrm{~s}$ and $50 \mathrm{~s}$ respectively. Subunits thus obtained were dialyzed and concentrated in a single operation using nltrafiltration in an Amicon cell with a UM-20E membrane. Upon several additions of a buffer containing $0.001 \mathrm{M} \mathrm{Mg(Acetate)}{ }_{2}$, $0.005 \mathrm{M}$ Tris-Cl ( $\mathrm{pH} 7.4$ ), the concentration of $\mathrm{K}^{+}$was lowered by a factor of 500 , the sucrose was lowered to less than $0.1 \%$ and the concentration of the $30 \mathrm{~S}$ ribosomes was adjusted to an absorbance (2600 A) of thirty. Then the solution was aliquoted, frozen in liquid nitrogen, and stored at $-15^{\circ} \mathrm{C}$, ready to be used for enzymatic prolysis.

\section{Preparation of 16S RNA}

A 305 ribosome solution of concentration not greater than $2 \mathrm{mg} / \mathrm{mI}$ was deprotenized with phenol at room temperature according to the following procedure. One volume of water-saturated phenol $\left(24^{\circ} \mathrm{C}\right)$ was shaken for 10 minutes with one volume of the ribosome auspension, and the aqueous phase separated after centrifugation. The Ionic strength of the aqueous phase was then increased with $1 / 10$ volume of $20 \% \mathrm{Na}$. Acetate and the RNA precipitated at $-15^{\circ} \mathrm{C}$ with 3 rolumes of ethanol. After the white precipitate was sedimented at $22,000 \mathrm{~g}$ for 20 minutes, the pellet was redissolved in about one rolume of $0.005 \mathrm{M}$ Tris-Cl (pH 7.4), and the RNA was again precipitated vith ethanol after the addition of $20 \% \mathrm{Na}$ Acetate. The precipitation step was done three times. This RNA, free of phenol, was dissolved in 
$0.005 \mathrm{M}$ tris to an absorbance $\left(2600 \mathrm{~A}\right.$ ) of 30 and stored at $-15^{\circ} \mathrm{C}$ in small aliquots.

By extracting unfractionated RNA with phenol as a function of the eoncentration of the RNA, it was possible to show that the ratio of 165 to 235 was abnormally low for input concentrations greater than $1.5 \mathrm{mg} / \mathrm{ml}$. Best recoveries of $16 \mathrm{~S}$ RNA were obtained working at $1 \mathrm{mg} / \mathrm{ml}$ or less, and using one volume of phenol at room temperature.

4. The Ribonuclease $A$

Ribonuclease A (bovine pancreas) from Worthington Co. was dissolved in 250 Micro grams per milliliter in $0.005 \mathrm{M}$ Tris-Cl (pH 7.4,double distilled water used). Stock solutions from 250 to $25 \mu \mathrm{g} / \mathrm{ml}$, made at room temperature in pyrex glass and stored at $4{ }^{\circ} \mathrm{C}$ in pyrex vials, gave constant activity over a period of months. Dilutions of low concentrations of enzyme were not stored because they were found to lose activity in a matter of hours.

\section{The Hydrolysis}

Hydrolysis of 30S ribosomes and I6S RNA was performed at Gyme-to-substrate molar ratios of 0.01 to 0.001 , and at $0^{\circ} \mathrm{C}$. The Ionic conditions chosen, $0.005 \mathrm{M} \mathrm{Mg(Acetate)})_{2}, 0.005 \mathrm{M} \operatorname{Tris}(\mathrm{pH}$ 7.2), were those found to give a maximum rate of RNA hydrolysis (15). A typical hydrolysis kinetics point was obtained by mixing in a $6 \times 50$ m Kimax culture tube the following volumes: 20 microliters $(\lambda)$ of Hiquoted RNA, 10 $\lambda$ of $0.005 \mathrm{M}$ Tris buffer, $10 \lambda$ of $0.025 \mathrm{M} \mathrm{Mg}$ (Acetate) 2 (in Tris buffer), and $10 \lambda$ of $0.01 \mathrm{mg} / \mathrm{ml}$ of RNase A. At a given time 
between 0 and 60 minutes of incubation, the reaction was stopped by adding $10 \lambda$ of $2 \%$ sodium dodecylsulfate (SDS;Matheson, Coleman \& Bell Co.) and the tube stood at room temperature afterward. The density of the seacted sample was increased with a few grains of sucrose.

Zero-time controls with and without RNase showed that hydrolysis did not continue in the presence of $0.4 \%$ SDS even at room temperature for several hours. To test whether the adsorption of RNase to the glass พลง Ignificant, controls were also run in polyethylene tubes, and the results showed no significant difference in activity.

\section{The Polyacrylamide Gels}

Acrylamide, $N, N^{\prime}-$ methylene bisacrylamide, and $N, N^{\prime}, N^{\prime}, N^{\prime}-$ Wanethylethylenediamine (T.M.E.D.) were purchased from Eastman Chemicals. The gels were polymerized and kept in E buffer $(0.001 \mathrm{M}$ EDTA, $0.02 \mathrm{M} \mathrm{Na}$ (Acetate), $0.04 \mathrm{M} \mathrm{Tris-Cl} \mathrm{pH} \mathrm{7.2).}$

I found that the method of Bishop (16) for the preparation of Plyacrylamide gels for the analysis of RNA can be modified for the sake of simplicity. His method calls for the recrystallization of the wrylamide and the $\mathbb{N}^{N^{\prime}}$-methylenebisacrylamide, and for presoaking the gels for several days. Gels of recrystallized materials were made and presoaked for about ten days. Gels of un-recrystallized materials were also made and allowed to presoak for 8 and 24 hours. Then the three kinds of gels were scanned versus distance along gel in the ultraviolet between 2600-2900A, before and after passing a 5-mAmp current through them in the electrophoresis buffer (prerun). No 
Mificant difference was found in the background level of all gels after 20 minutes of prerun. All of the scans had a smooth, low and flat background, except for the gels with long presoaking which probably whibited some light scattering from dust.

For a typical batch of 48 gels of $4.4 \%$ acrylamide, the polymerization reaction was started in a $250 \mathrm{ml}$ flask in the following manner: $42.5 \mathrm{ml}$ of $15 \%(\mathrm{w} / \mathrm{v})$ acrylamide, $30 \mathrm{ml}$ of $0.725 \%(\mathrm{w} / \mathrm{v})$ of bisacrylamide, $7.3 \mathrm{ml}$ of $20 \mathrm{xE}$ buffer, and $64 \mathrm{ml}$ of $\mathrm{H}_{2} \mathrm{O}$ were first mixed and degassed for 30 seconds. Then $60 \lambda$ of T.M.E.D. solution was added followed by the addition of $1.2 \mathrm{ml}$ of freshly made $10 \%(\mathrm{w} / \mathrm{v})$ aqueous solution of ammium persulfate. Immediately after, $3 \mathrm{ml}$ aliquots were placed in vertical plexiglass tubes of $1 / 4$ " internal diameter. The solution was Dlymerized for 30 minutes, and the gels were then extruded and soaked in $\mathrm{E}$ buffer for a minimum of eight hours.

\section{Electrophoresis of the RNA}

The gels to be used in an electrophoretic run were cut to 10.5 $\mathrm{cm}$ in length, leaving the ends flat and straight. Before loading the sample, a $5 \mathrm{mAmp} / \mathrm{gel}$ current was passed through the gel for 30 minutes (pre-run) in E-SDS ( $0.2 \%$ SDS) buffer. The total reacted volume (little

over 60) was loaded onto a gel, and then electrophoresed with a current of $5 \mathrm{mAmp} / \mathrm{gel}$ for 3 or 3.5 hours using a Canalco disctrophoresis instrument.

\section{Reading the Gels}

The gels were scanned for absorbance at $2600 \mathrm{~A}$ in a DU-Gilford trophotometer with mechanical gel scanner and recorder. Quantitative 
melysis of the products of the reaction was done by both cutting the tracing of the recorder and weighing the areas, and by direct measurement of the heights of the bands. To supplement the results from the U-scan, gels in $0.2 \%$ SDS were first washed in distilled water in a test tube for 24 hours (with one change of water) and then stained with me-tenth volume of $0.2 \%$ methylene blue in $0.4 \mathrm{M}$ acetate buffer (pH 4.7). The staining could be stopped anywhere between 4 and 8 hours by placing the gel in a test tube with distilled water, with no need of further washing. 


\section{RESULTS}

Protein-free 16S rRNA was mildly hydrolyzed with $0.02 \mu \mathrm{g} / \mathrm{ml}$ of pRNase, and the products of the reaction were analyzed in a polyacrylamide gel to give the pattern shown in figure 1 . Nine product bands even at the earliest kinetic points were observable by either staining the gel with methylene blue or by scanning the gel at $2600 \mathrm{~A}$. These nine bands correspond to nine discrete RNA fragments whose molecular weights have been calculated from their individual mobilities (16) and reported in table 1 .

In order to follow a brief history of the bands of figure I, I have arbitrarily divided the course of mild hydrolysis into two stages according to the remaining amount of input RNA namely, when intact $16 \mathrm{~S}$ RNA remaining is $25 \%$ or more, and when it is less than $25 \%$. Toward the middle of the first stage most of the new bands were observed to attain maximum height and best resolution. In the second stage, band $16 \mathrm{~A}$ lost considerable height, the general background was raised, and the other bands lost their original shape. Bands $16 \mathrm{~A}$ and $16 \mathrm{G}$ remained particularly prominent until the onset of the second stage (figure $1 b, 1 c$ ).

$30 S$ ribosomal subunits, in ionic conditions identical to those used for the protein-free rRNA, were midly hydrolyzed with $0.4 \mu \mathrm{g} / \mathrm{ml}$ of pRNase, The products of the reaction were deproteinized with SDS, and then analyzed in a polyacrylamide gel to give the pattern shown in Pigure 2. Six small bands were observable by either staining the gel 
with methylene blue or by scanning the gel at 2600A. Bands $30 \mathrm{~A}$ and $3 O B$ appeared a.lmost fused into one broad and flat band, but were well resolved bands in the stained gels. Notice the $30 \mathrm{C}$ and $30 \mathrm{D}$ are the ughest bands among the products. The molecular weights of the RNA ragments range between 0.5 and 0.02 times that of the $16 \mathrm{~s}$, and their values are given in table 2 .

By comparing the gel patterns of the RNA fragments from proteinfree rRINA and 30 s subunits, two major observations were made.

a) Upon reaction with the ribonuclease, the protein-free RNA generated more fragments than the RNA in the ribosome. b) The bands that exhibited greater absorbance did not correspond to the larger molecular weight, but rather to some intermediate molecular weight fragments. The kinetic study of the hydrolysis of RNA was done by measuring the height of the $16 \mathrm{~s}$ band of the gel pattern as a function of time since the height of the band is directly proportional to the concentration of unhydrolyzed 16S RNA. In order to learn the order of the kinetics of the reactions, the data from both protein-free 16S RNA and 30 s ribosomes were treated as a zeroth-order, first-order, and Mecond-order reaction with respect to the substrate. The rate of lecomposition of a reactant that follows zeroth-order kinetics obeys the rate equation $\mathrm{dC} / \mathrm{dt}=-\mathrm{k}_{0}$, whose integrated form,

$$
\mathrm{C}_{0}-\mathrm{C}_{t}=\mathrm{k}_{0} \mathrm{E} \quad \text { Equation } 1 \text {. }
$$

represents a straight line of slope $\mathrm{k}_{0}$. In turn, the rate of decomposition of a reactant that follows first-order kinetics obeys the rate equation $\mathrm{dC} / \mathrm{dt}=-\mathrm{k}_{1} \mathrm{C}$, whose integrated form, 


$$
\text { In } c_{0} / C_{t}=k_{l} t \quad \text { Equation } 2
$$

thus plotting In $\mathrm{C}_{\mathrm{O}} / \mathrm{C}_{\mathrm{t}}$ versus $\mathrm{t}$ gives a straight line of slope $\mathrm{k}_{1}$. If the decomposition of a reactant follows second-order kinetics, then the rate equation is $\mathrm{dC} / \mathrm{dt}=\mathrm{k}_{2} \mathrm{C}^{2}$, whose integrated form,

$$
1 / C_{t}-1 / C_{0}=k_{2} t \quad \text { Equation } 3
$$

thus plotting $\left(\frac{1}{C t}-\frac{1}{C_{0}}\right)$ versus $t$ gives a straight line of slope $k_{2}$. Pseudo first-order and pseudo second-order rate constants $\left(k_{1}^{\prime}, k_{2}^{\prime}\right)$ wich are proportional to the enzyme concentration, are commonly used for enzyme-catalyzed reactions.

The kinetic data for the hydrolysis of protein-free 16S RNA best fit equation 2 for the first stage of the reaction (figure $3 b$ ). For an enzyme concentration close to $0.01 \mu \mathrm{g} / \mathrm{ml}$, the pseudo first-order rate constant $\left(k_{1}^{\prime}\right)$ was estimated from the slope of figure $3 b$ to be equal to $2.6 \times 10^{-2} \min ^{-1}$, and the corresponding half-life for the rotein-free 16 $\mathrm{S}$ RA was approximately 25 minutes. When the same set of data was treated according to the zeroth-order and second-order rate equations, curved lines were observed to fit the points (figure $3 a$ ). It was observed that the order of the reaction could change if the extent of hydrolysis passed the first stage.

The kinetics for the hydrolysis of $30 \mathrm{~S}$ ribosomes with 0.4 and $0.8 \mu \mathrm{g} / \mathrm{ml}$ pRNase was found to fit a straight line according to equation 3 (figure 4c). Starting with an input of $0.5 \mathrm{mg} / \mathrm{ml}$ of the mbstrate, the pseudo second-order rate constants were $8.6 \times 10^{-2}$ and $17.2 \times 10^{-2} \mathrm{ml} / \mathrm{mg} \cdot \mathrm{min}$, and the half-life times were 24 and 12 Minutes for 0.4 and $0.8 \mu \mathrm{g} / \mathrm{ml}$ of pRNase respectively. Attempts to 
pit these data to equations 1 and 2 for zeroth-order and first-order unetics respectively, gave the curves shown in figures $4 a, b$. When $30 \mathrm{~S}$ ribosomes and I6S RNA were treated at RNase concentrations which largely hydrolyzed 16S RNA, little or no hydrolysis of the 30 S ribosomes was observed (figure $3 \mathrm{~b}$ ). It was therefore necessary to employ for the ribosomes RNase in concentrations 20 to 40 times that needed for the protein-free RNA. 


\section{DISCUSSION}

The observation that mild hydrolysis of protein-free 16s rRIA results in a number of discrete fragments suggests the RNA has a tertiary structure. The appearance of discrete fragments of rRNA upon mild hydrolysis has been already reported for yeast rRNA and fractionated E. colì rRNA (12), rabbit reticulocyte 19S rRNA (13), and for $23 \mathrm{~S}$ rRNA from E. coli (17). Evidence is given that a tertiary atructure assumed by the RNA is selectively exposing the few sites that are primarily hydrolyzed while there exist many other sites which remain temporarily "guarded" by the tertiary structure of the RNA. The seven larger fragnents ( $16 \mathrm{~A}-16 \mathrm{G})$, produced during the first stage of mild hydrolysis of the protein-free RNA, are equally hydrolyzable into smaller fragments during the second stage of the reaction (figure ld). It has been reported (13) that during the course of mild hydrolysis of rRNA, the fragment pattern changes as the large fragments are hydrolyzed into smaller fragments which, in turn, originate new bands. Furthermore, small fragments can be produced by the action of pRNase (about 2S) of rRNA which are known to contain both helical and single stranded regions (19). Therefore, the presence of many hidden sites strongly suggests that there is a tertiary structure in the protein-free 16S RNA determining, over the dictates of the primary and secondary structures, which sites are most likely to be hydrolyzed.

By examination of the molecular weights in table 1 , it is possible to suggest a mechanism for the hydrolysis of protein-free l6s rRNA. It is likely that fragment 16A (M.W. 440,000) proceeds from the $16 \mathrm{~S}$ 
by a one-break reaction since that $16 \mathrm{~A}$ has a very high molecular weight, and the enzyme-to-substrate molar ratio in this hydrolysis is very low (about $1 / 1000)$. Making also the consideration that the absorbance of RNA fragments of molecular weight less than 100,000 is quite low, it is then reasonable to expect from the reaction an RNA component with a molecular weight in the neighborhood of 110,000. Fragment 16G (M.W. 130,000) fits best the desired condition and, with its molecular weight reassigned as 110,000 , it could be used as a marker together with I6S to correct the weights of the intermediate fragments. Taking the porrected molecular weights of table I, I propose that the hydrolysis in question could be initiated by, at least, two simple parallel reactions

a)

$16 \mathrm{~s}$ 550

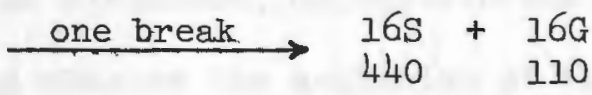

b)

$$
16 \mathrm{~s}
$$

550

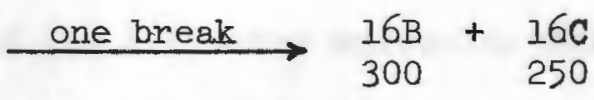

The RNA fragments shown in figure 2 suggest that the 30 S subunit has a definite conformation. Two features of figure 2 deserve to be discussed. a) The fact that bands 30C and 30D are the highest bands could be due to a major accumulation of these fragments or to a high content of single stranded regions in the fragments. b) All of these are small bands which are observed to appear simultaneously even at the earliest kinetic points thus ruling out the accumulation of some intermediates.

For making a comparison between the fragment patterns of Iigures 1 and 2, it should be considered that the conformation of the rRNA in the ribosome determined by the interactions present between the 
rRNA and the ribosomal proteins. It is apparent from figures 1 and 2 that there are fewer sites available in the ribosome. Bands $16 \mathrm{~A}$, $16 \mathrm{~B}$ and $16 \mathrm{C}$, of figure 1 , are clearly not present in figure 2 . A narrow site on the RNA might be strategically exposed after the removal of the proteins so that fragments $16 \mathrm{~A}$ and $16 \mathrm{G}$ could be produced. It is pasible that if three out of the nine fragments in figure 1 do not oofncide with any of those in figure 2 at least 3 and perhaps 6 , or even 0119 , of them are characteristic of the protein-free rRNA. Since no two RNA fragments from the hydrolysis of the subunit add up to 550,000 daltons, it is concluded that no single-break reaction could be detected in the present conditions. At the high enzyme mcentration used for the ribosomes, multiple-break reactions are more probable and they tend to obscure the mechanism of the total reaction. However, since the sum of the corrected molecular weights (table 2) of fragments $30 \mathrm{~A}$ through $30 \mathrm{~F}$ equals 583,000 daltons, it is possible to suggest at least one mechanism for the total reaction. The mechanism would require the existence of $n$ neighboring sites which originate n equally probable reactions on the ribosome. A model of the 305 aibosome that makes the mechanism feasible could be one having a large surface protected by protein, and a "cavity" by which the enzyme could reach unprotected regions of the RNA. This interpretation would imply that the reaction for the entire set of sites would occur by random Pollisions while $n-1$ of the sites would not react independently, as if the enzyme remained "trapped" in a cavity after the first reaction. 
The hydrolysis of protein-free 16\$ RNA follows first-order Inetics and the hydrolysis of $30 \mathrm{~s}$ ribosomes is found to fit a secondorder rate equation when the half-lives of both substrates are comparable. There is not a clear cut differentiation between the first, second and seroth-order plots for the rate data for $16 \mathrm{~S}$. This is still mexplained although the complexity of the reaction and the particular degree of saturation of the enzyme may determine this behavior. The geveral sites open to hydrolysis in the protein-free RNA may originate parallel reactions of diverse order which, on the average, follow first order kinetics. The order of the kinetics for 16S RNA may be a function of the extent of the reaction. On the other hand, the hydrolysis of 30 Sibosomes was not done at saturation of the enzyme (figures $4 \mathrm{a}, \mathrm{b}$ ), and the order of the kinetics did not change with the extent of the reaction. It should be mentioned here that hydrolysis of $50 \mathrm{~s}$ subunits and 23S RNA, under conditions identical to those for the 16S RNA, were found to follow first-order kinetics(17).

The hydrolysis rate of the protein-free 16s rRNA is substantially greater than that of the $30 \mathrm{~S}$ ribosomes. In order to make the half-lives about 25 minutes, the subunits required a 40-fold increase of the ribonuclease. This striking difference between the 30 s subunit and $16 \mathrm{~S}$ RNA contrasts with the fact that the 50 s subunit has a first-order rate constant equal to twice that of the 23S RNA (17). The RNA in the 30 S ribosomal subunit is mostly protected from the action of the ribonuclease. The significantly smaller hydrolysis rate of the ribosomes could be partly a result of shielding by the 
proteins, and by an increase in the energy of activation of the reaction caused by a change in conformation due to the protein-RNA interactions. It is not clear yet whether the conformation of $16 \mathrm{~S}$ rRNA in the protein-free state is different from that in the ribosomal state, however, data presented here indicate that they are not necessarily the same. Two facts are underlying this statement. I) at least, fragments $16 \mathrm{~A}, 16 \mathrm{~B}$, and $16 \mathrm{C}$ do not appear in the hydrolysis of the gubunits indicating that there exist regions open to hydrolysis in the protein-free state which are not available in the ribosomal state. 2) The hydrolysis rate of the 30 s subunit is low enough to suspect that the RNA may undergo conformational change upon removal of the proteins. 
Figure 1

Mild hydrolysis of $16 \mathrm{~S}$ rRNA

a. Input RNA in a $4.4 \%$ polyacrylamide gel. Single band of completely undigested protein-free 16S rRNA to which SDS was added before the pRIase.

b. Fragment pattern corresponding to the middle of the first stage of mild hydrolysis of protein-free $16 \mathrm{~S}$ rRNA. The reaction was carried out with $0.02 \mu \mathrm{g} / \mathrm{ml}$ of pRNase.

c. Fragment pattern in the second stage of mild hydrolysis of protein-free 16S rRNA. Note the differences of this pattern as compared to that in figure Ib.

d. Fragment pattern following the second stage of mild hydrolysth of protein-free 16S rRNA. The larger molecular weight fragment further disappear by slower reactions suggesting the presence of more hydrolyzable sites. 


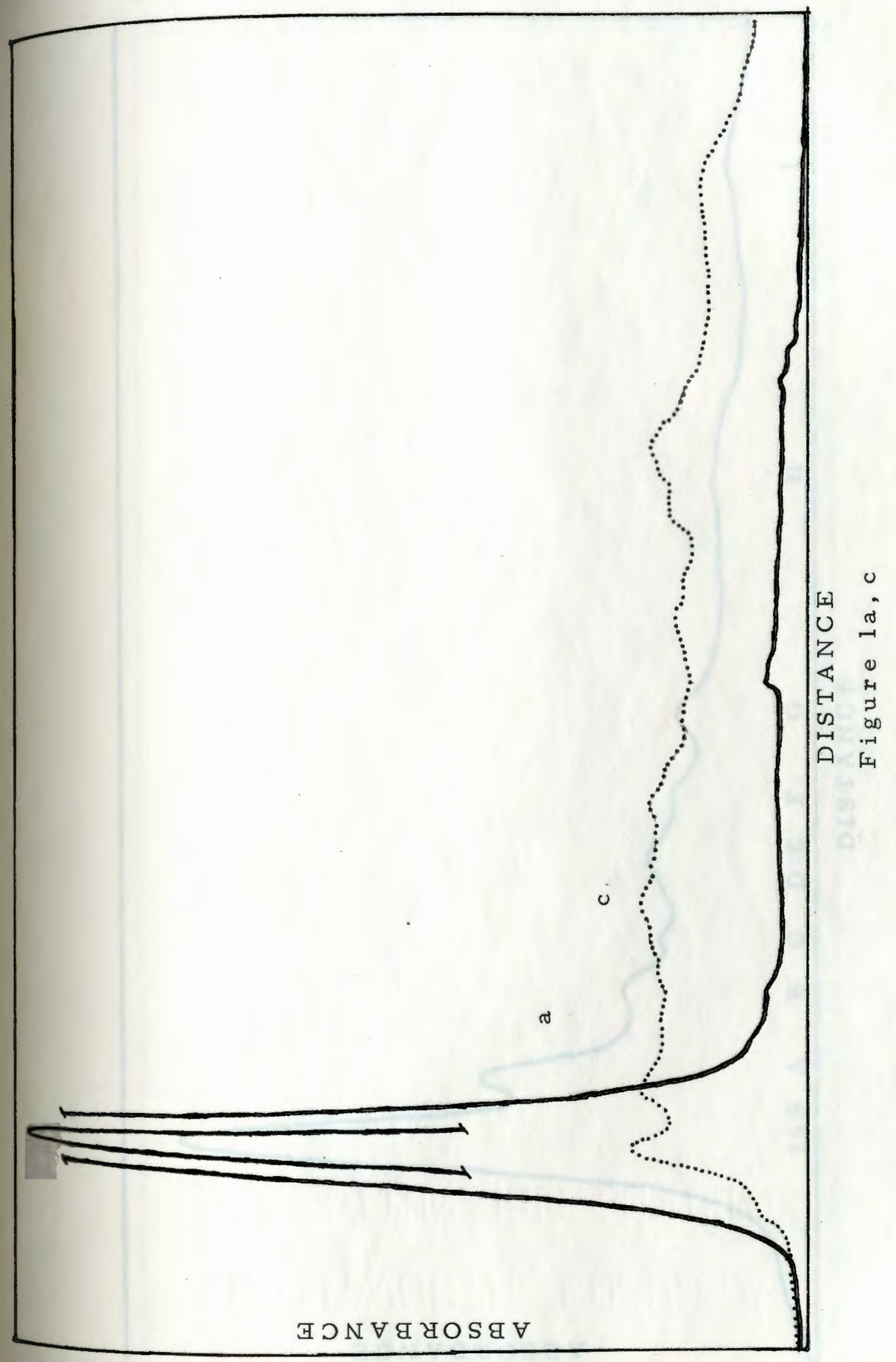




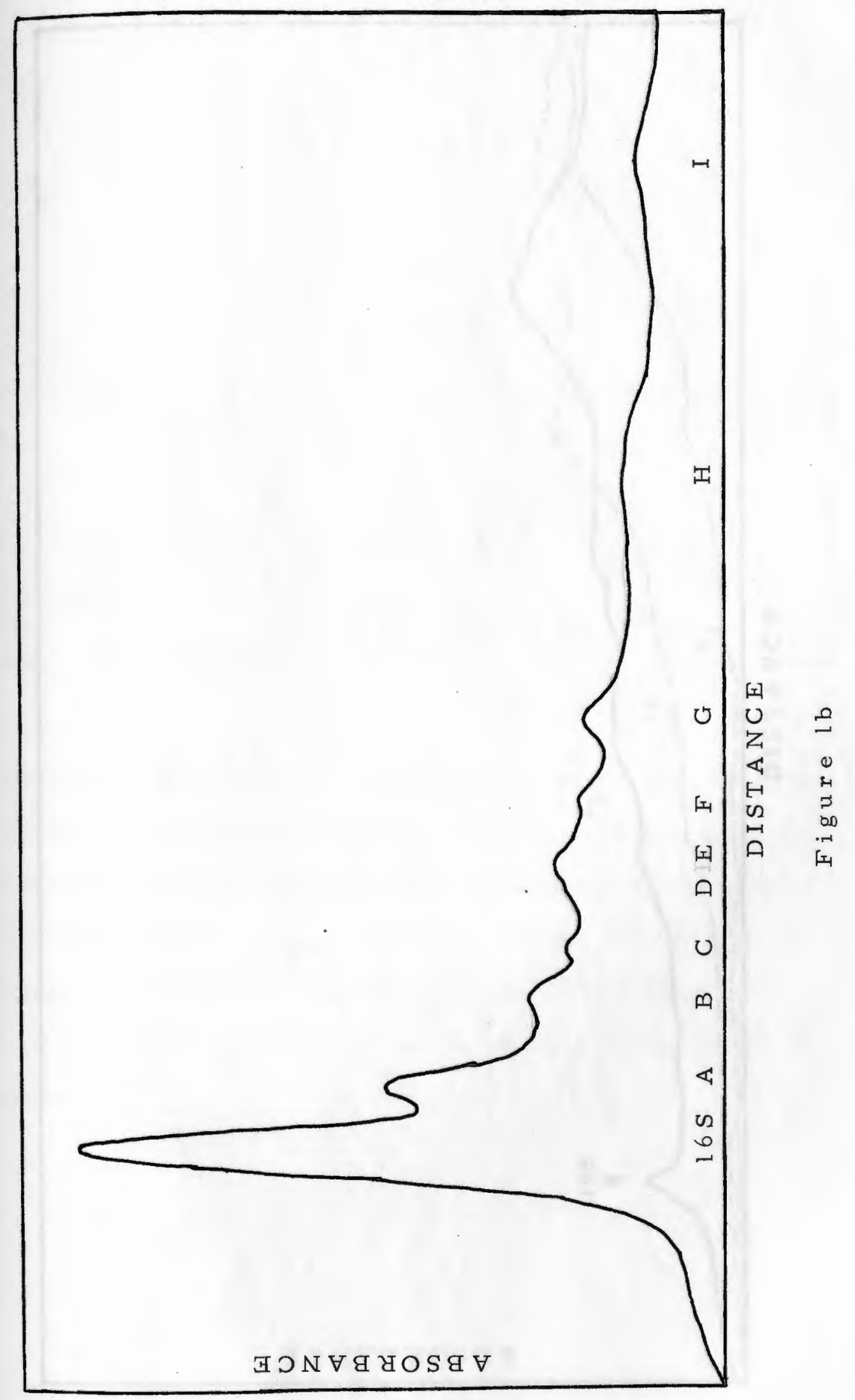




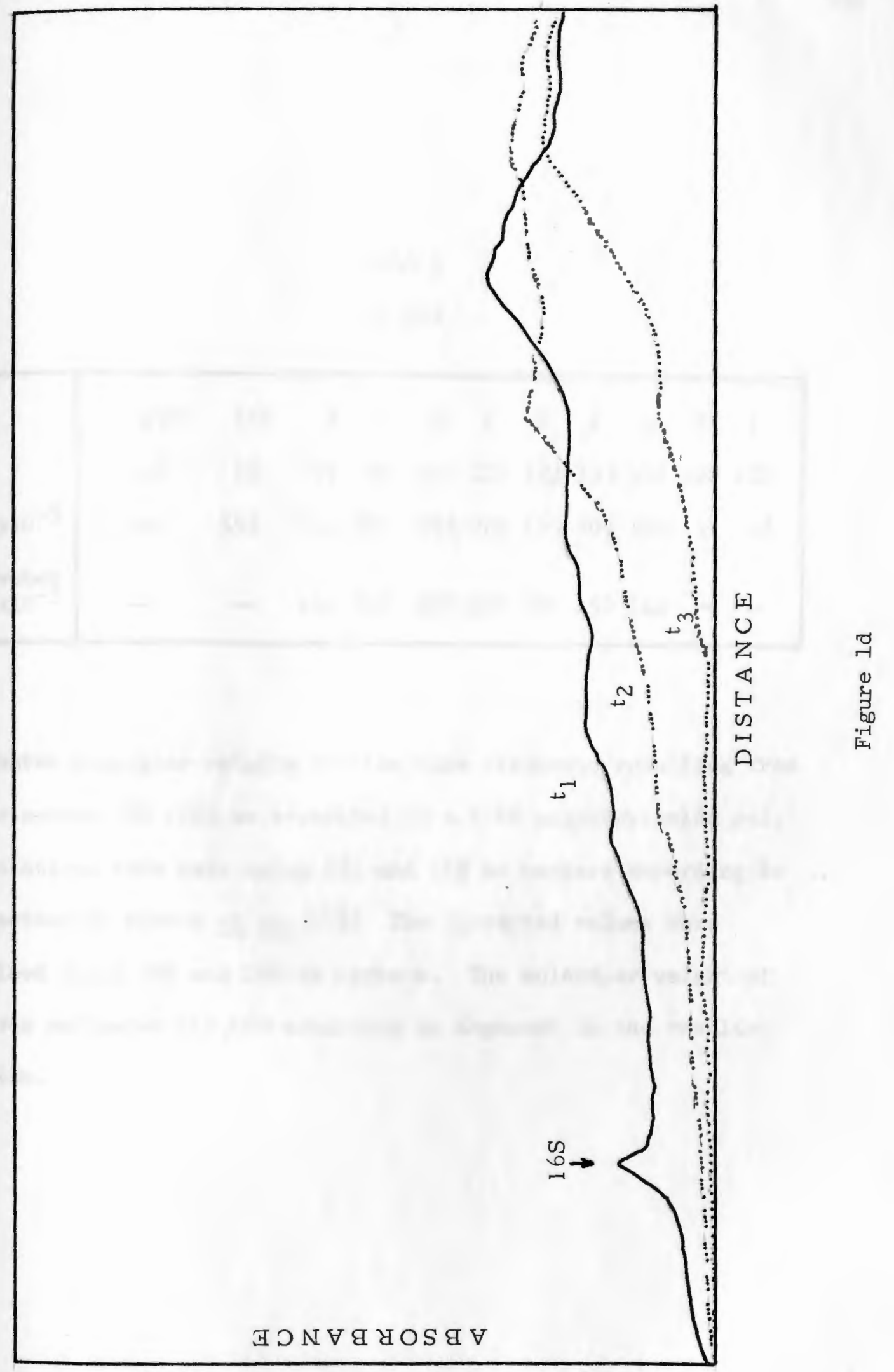


TABIE 1

16S RNA

\begin{tabular}{|l|rrrrrrrrrrr|}
\hline Band & $23 \mathrm{~S}$ & $16 \mathrm{~S}$ & $\mathrm{~A}$ & $\mathrm{~B}$ & $\mathrm{C}$ & $\mathrm{D}$ & $\mathrm{E}$ & $\mathrm{F}$ & $\mathrm{G}$ & $\mathrm{H}$ & $\mathrm{I}$ \\
$\mathrm{mm}$ & 12 & 66 & 77 & 95 & 101 & 114 & 122 & 133 & 148 & 192 & 251 \\
M.W.x10-3 & 1,100 & 550 & 450 & 325 & 288 & 225 & 195 & 160 & 120 & 51 & 18 \\
$\begin{array}{l}\text { corrected } \\
\text { M.W.x10-3 }\end{array}$ & - & - & 440 & 300 & 250 & 210 & 160 & 150 & 110 & - & - \\
\hline
\end{tabular}

Estimated molecular weights for the nine fragments resulting from protein-free 16S rRNA as separated in a $4.4 \%$ polyacrylamide gel. Calculations were made using $23 \mathrm{~S}$ and $16 \mathrm{~S}$ as markers according to the method of Bishop et al: (16) The corrected values were obtained using $16 \mathrm{~S}$ and $16 \mathrm{G}$ as markers. The molecular weight of $16 \mathrm{G}$ was estimated 110,000 according to argument in the results section. 
Figure 2

Fragment pattern from the hydrolysis of $30 \mathrm{~S}$ ribosomal subunits as analyzed in a $4 \%$ polyacrylamide gel. The product bands display maximum height attained during mild hydrolysis. The reaction was carried out with $0.4-0.8$ $\mu \mathrm{g} / \mathrm{ml}$ of RNase. The RNA from input ribosomes gave a single band undistinguishable from that in figure la. 


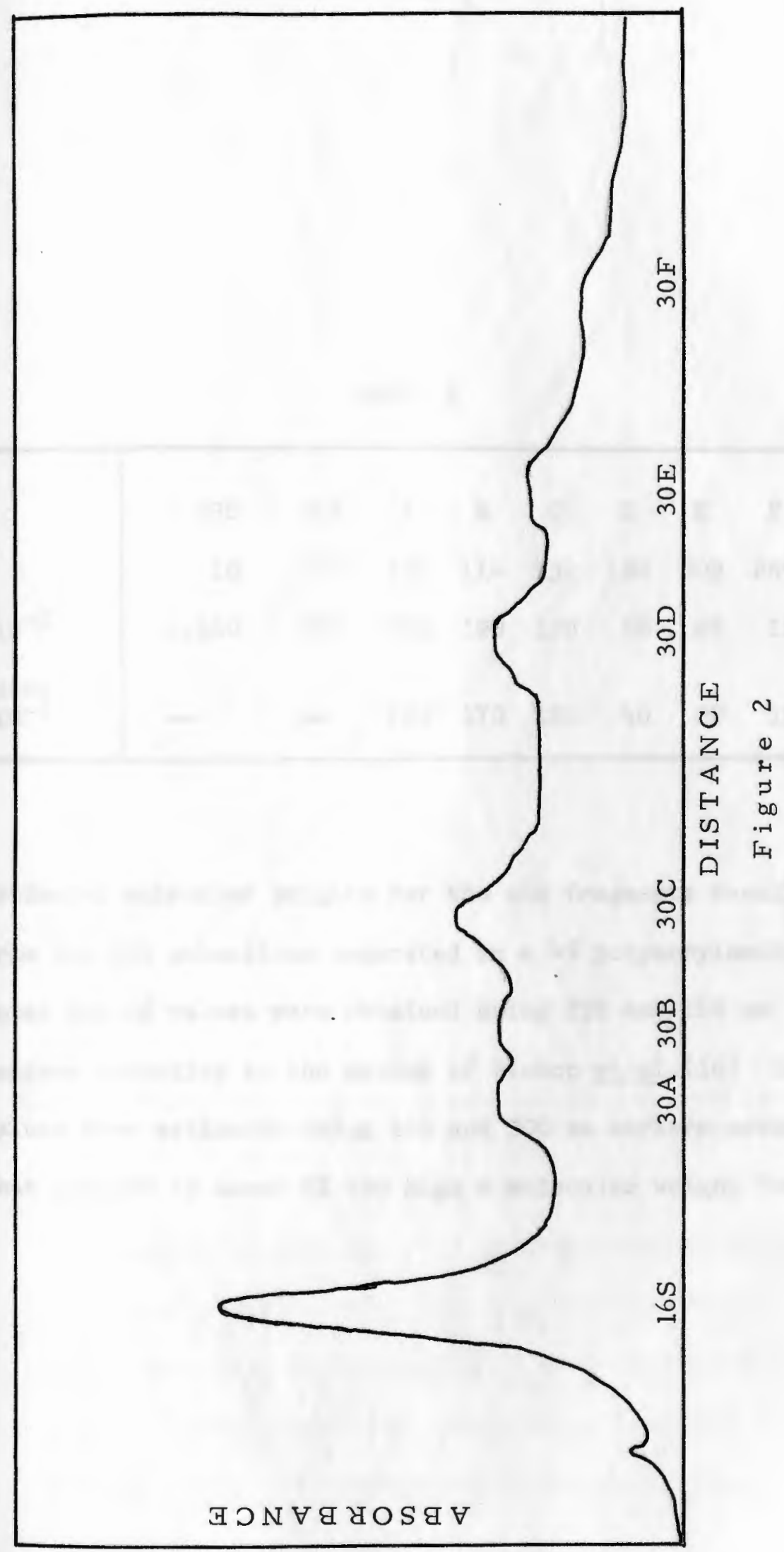


TABLE 2

\begin{tabular}{|l|rrrrrrrr|}
\hline Band & 235 & $16 S$ & A & B & C & D & E & $F$ \\
m.W.x & 10 & 60 & 101 & 114 & 132 & 180 & 209 & 240 \\
$\begin{array}{l}\text { corrected } \\
\text { M.W.x } 10^{-3}\end{array}$ & 1,100 & 550 & 242 & 190 & 130 & 50 & 28 & 15 \\
\hline
\end{tabular}

Estimated molecular weights for the six fragments resulting from the 30 s subunit as separated in a $4 \%$ polyacrylamide gel. Upper set of values were obtained using $23 \mathrm{~S}$ and $16 \mathrm{~S}$ as markers according to the method of Bishop et al.(16) Corrected vailues were estimated using $16 \mathrm{~s}$ and $30 \mathrm{C}$ as markers assuming that 130,000 is about $5 \%$ too high a molecular weight for $30 \mathrm{C}$. 
26.

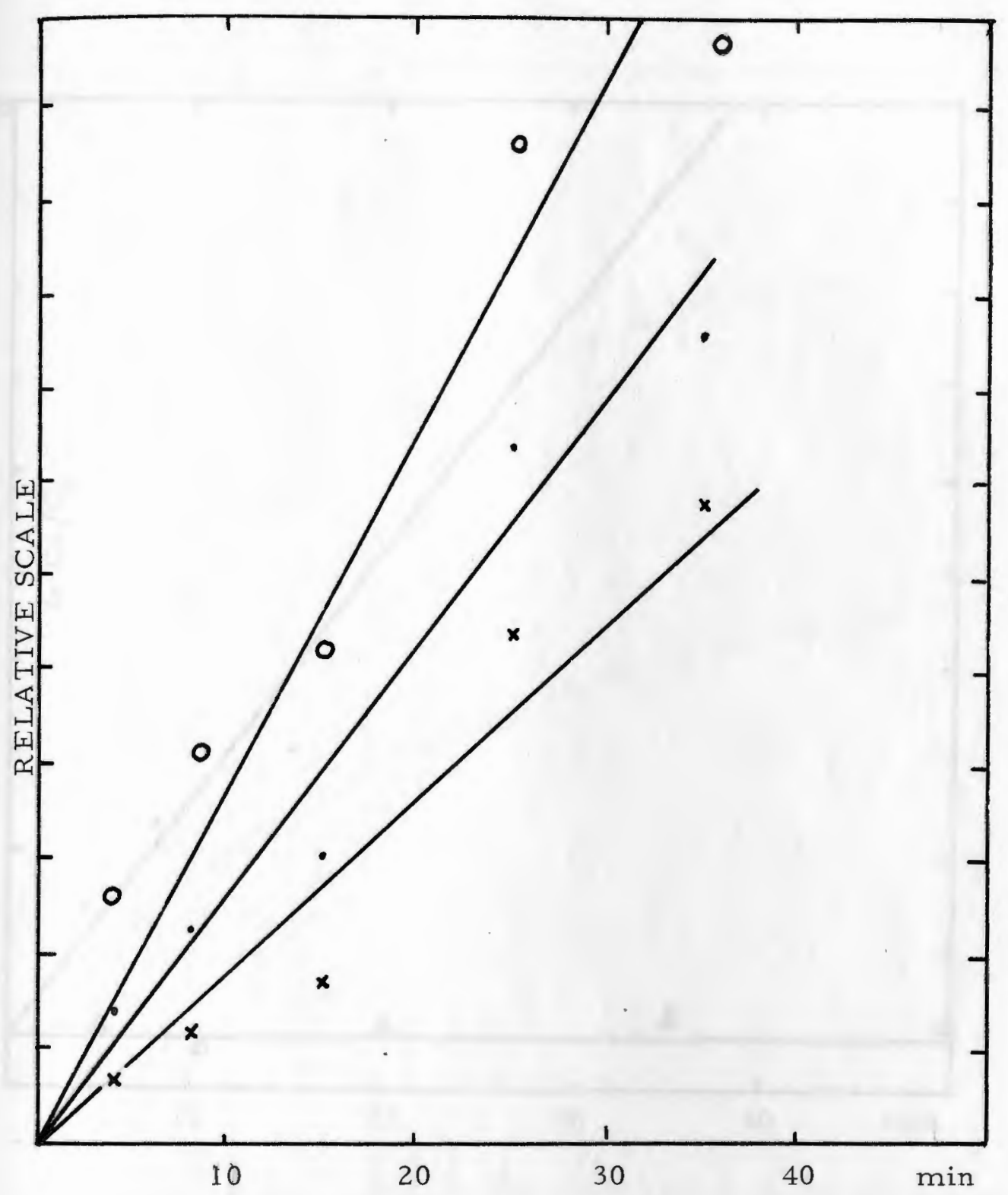

Figure $3 a$

Treatment of kinetic data for protein-free 16S RNA according to the zeroth-order (o), first-order $(\cdot)$, and second-order $(x)$ rate equations. Note that lower points acquire upward trend with zeroth-order treatment and downward trend with second-order treatment. Trends are opposite for upper points. 


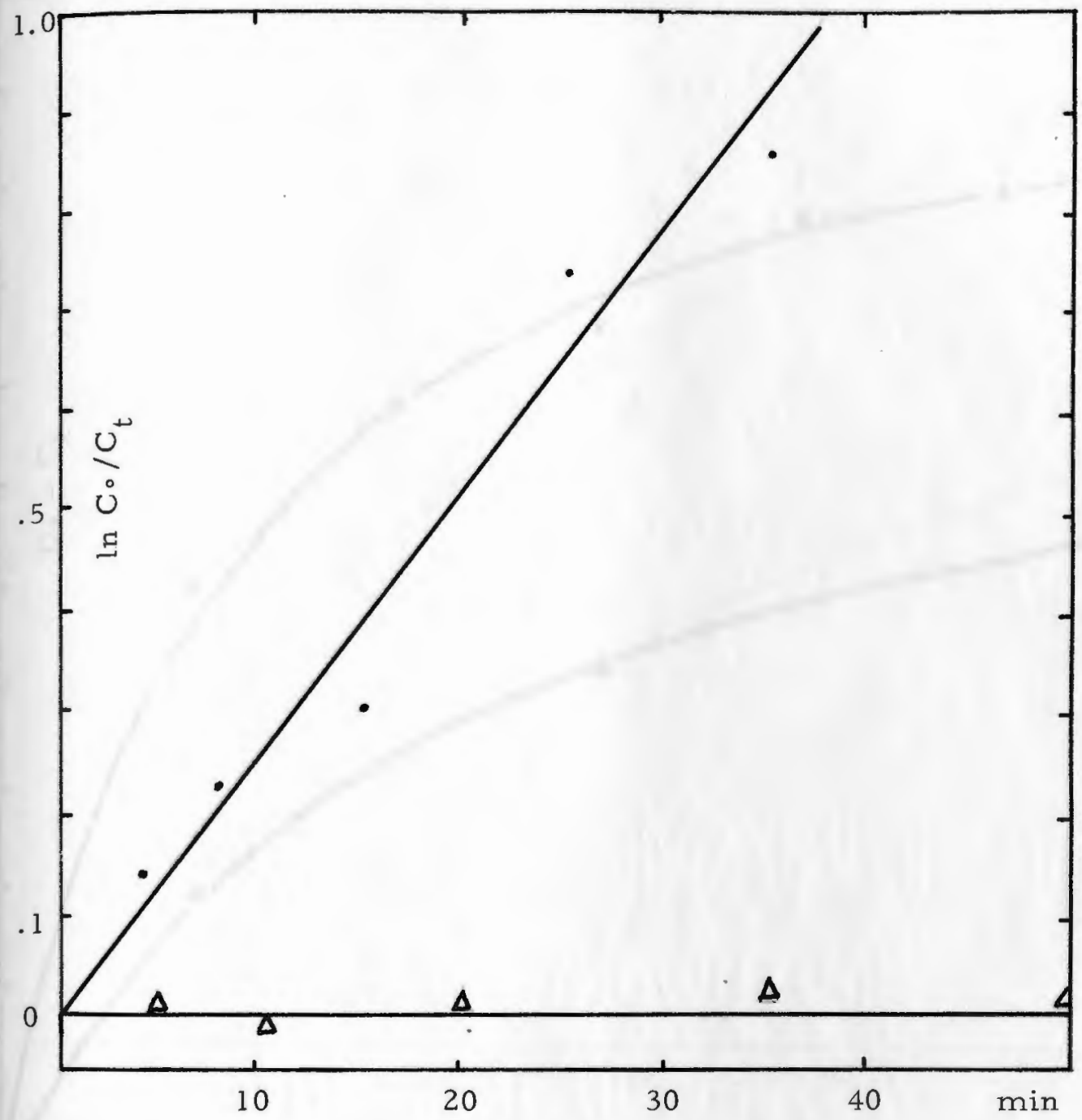

Figure 3b

Parallel hydrolysis of 16 S RNA and 30 S ribosomes

at about $0.01 \mu \mathrm{g} / \mathrm{ml}$ RNase. No appreciable hydrolysis of

the ribosomes was observed unless the enzyme concentration

was raised 20 times or more. The ionic conditions are these

given in the experimental section. (o)protein-free RNA; ( $\Delta$ ) 30S ribosomes. 
28 .

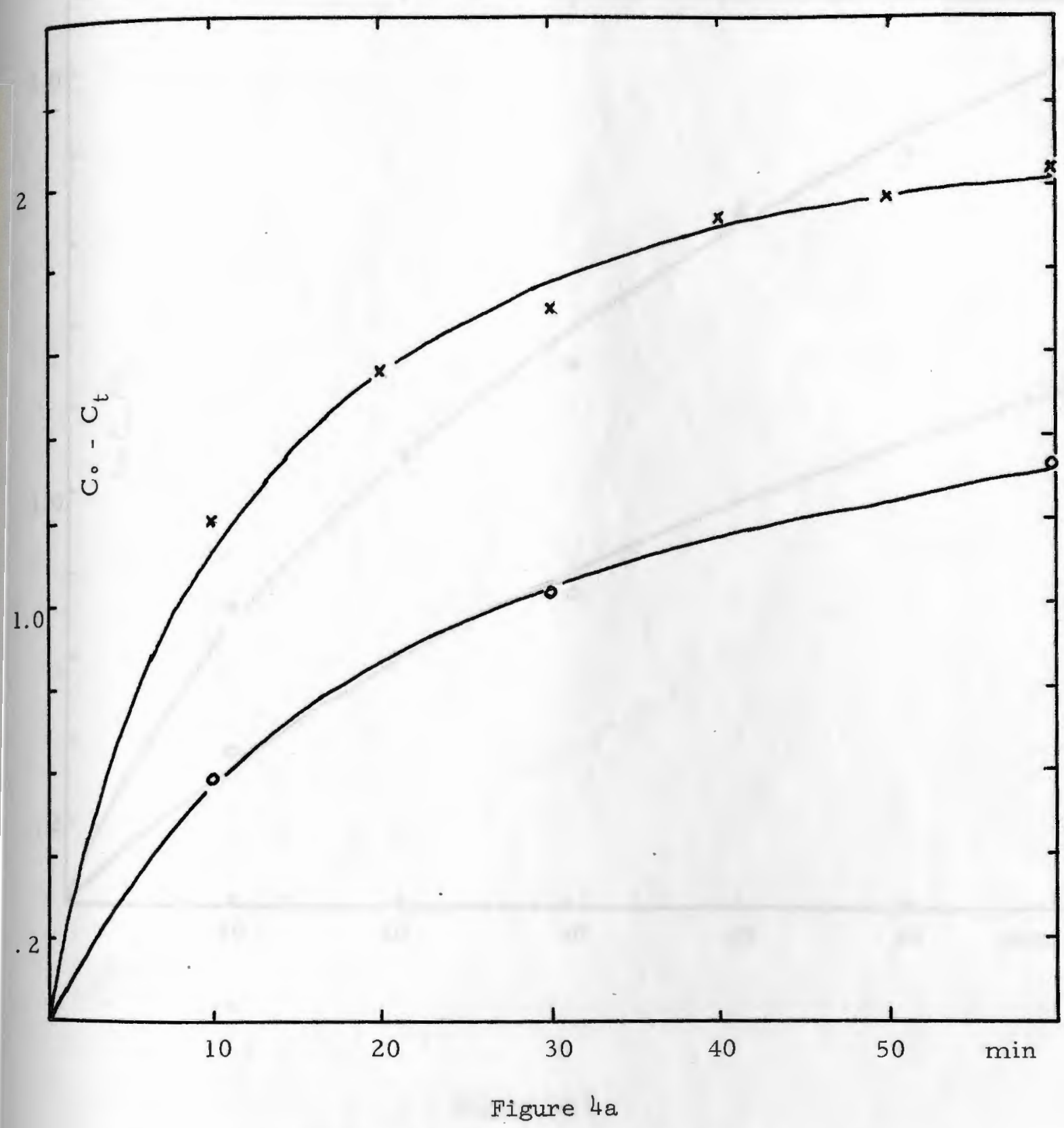

Zeroth-order kinetic plot of hydrolysis of 30 S ribosomal subunits under ionic conditions identical to those used for the protein-free rRINA. ( $x) 0,8,6$, 0 ) $0.4 \mu \mathrm{g} / \mathrm{ml}$ pRNase. 
29.

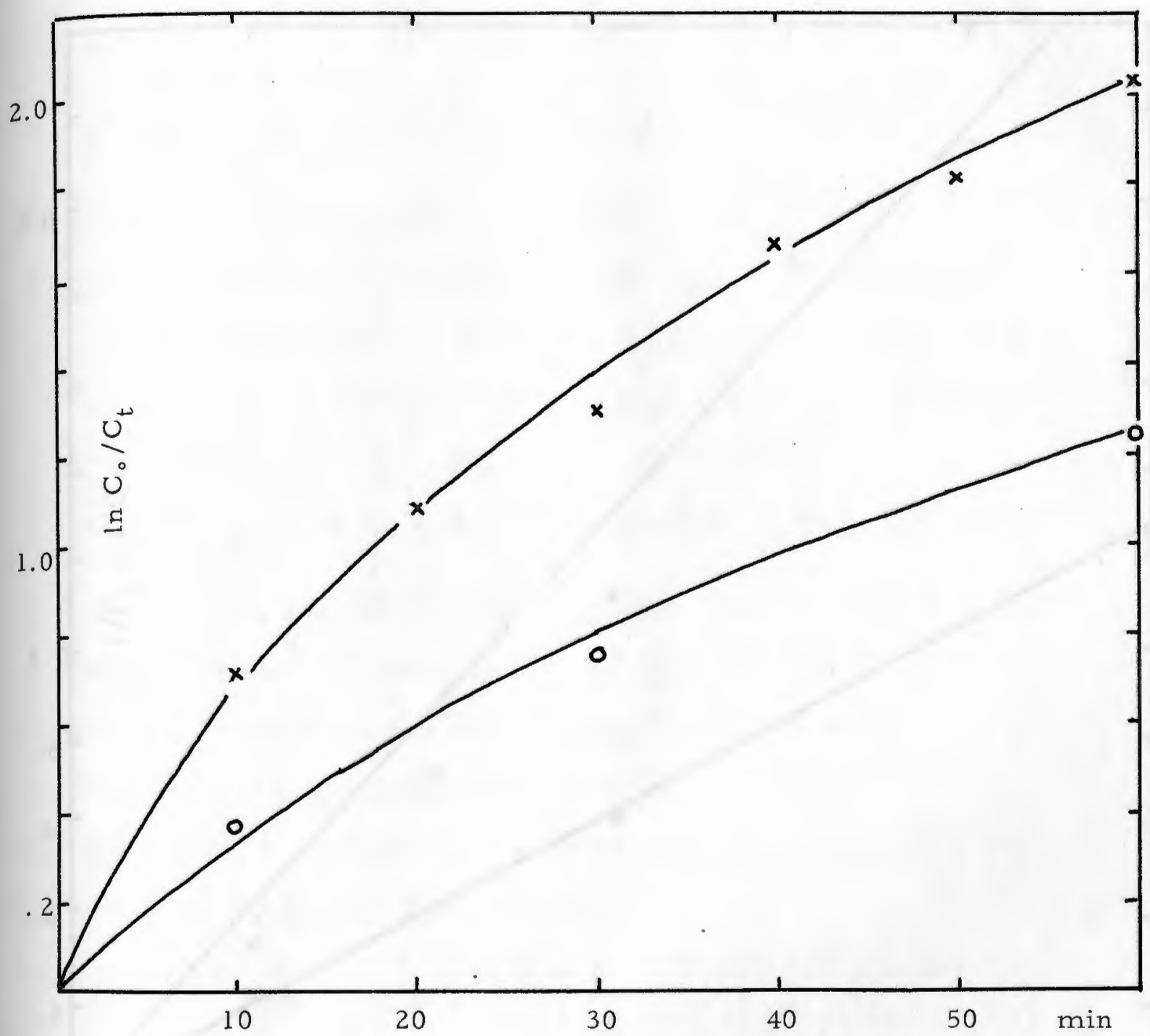

Figure 4b

First-order kinetic plot of the hydrolysis of 30 sibosomal

subunits with pRNase under ionic conditions identical to those used for the protein-free rRNA. ( $\mathrm{x}) 0.8,(\mathrm{o}) 0.4 \mu \mathrm{g} / \mathrm{ml}$ pRNase. 
30.

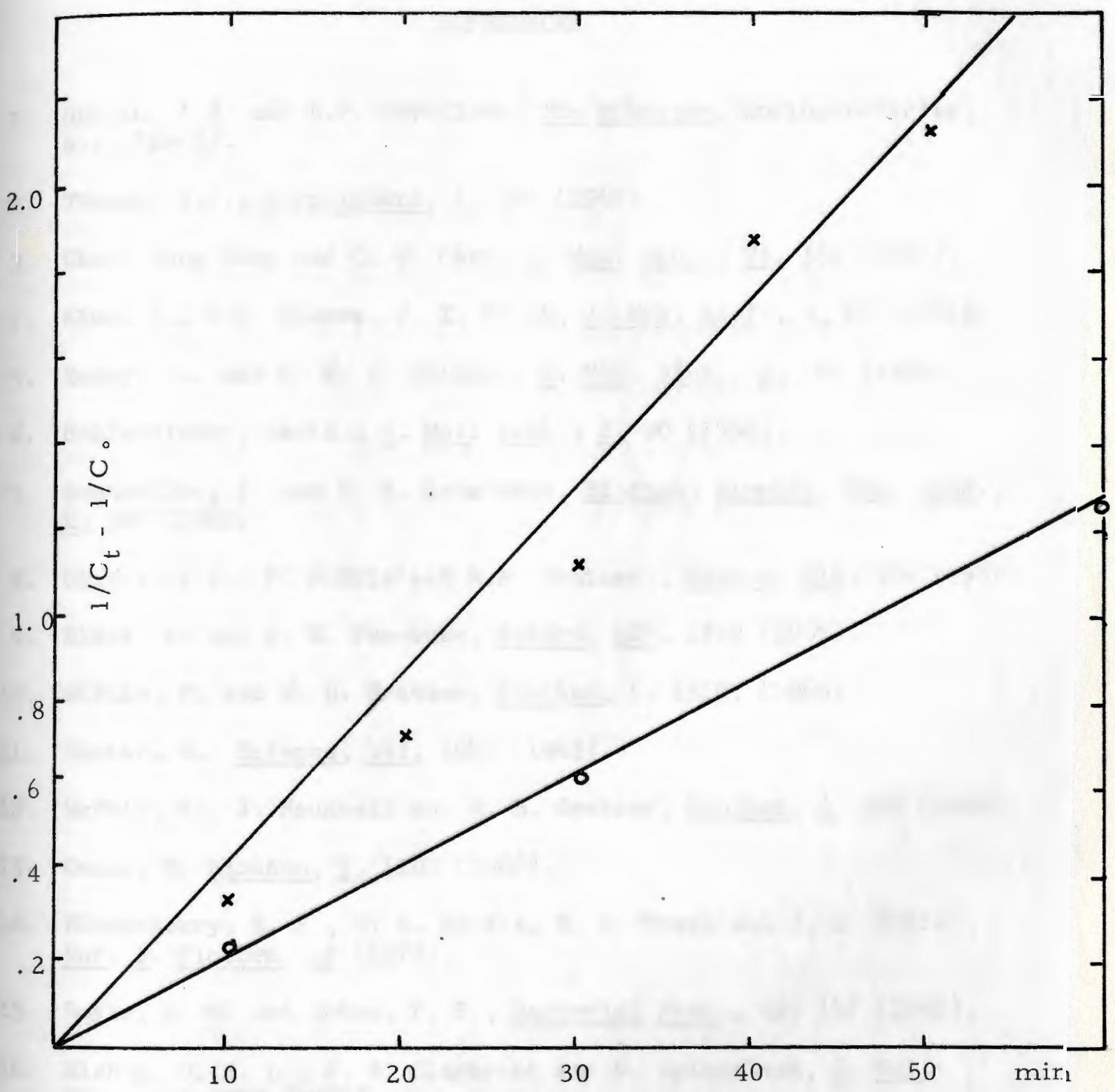

Figure $4 c$

Second-order kinetic plot of the hydrolysis of 30 S ribosomal subunits with pRNase under ionic conditions identical to those used for the protein-free rRNA. (x) 0.8 , (o) $0.4 \mu \mathrm{g} / \mathrm{ml}$ pRNase. 
REFERENCES

1. Spirin, A.S. and L.P. Gavrilova, The Ribosome, Springer-Verlag, NI.Y., (1969).

2. Thomas, G.J., Biopolymers, I, 325 (1969)

3. Choi, Yong Sung and C. W. Carr, J. Mol. Biol., 25, 331 (1967).

4. Klug, A., K.C. Holmes, J. T. Finch, J. Mol. Biol., 3 , 87 (1961).

5. Zubay, G., and M. H. L. Wilkins, J. Mol. Biol., 2 , 105 (1960).

6. Schlessinger, David., J. Mol. Biol., 2, 90 (1960).

7. Bonhoeffer, F. and H. K. Schachman, Biochem, Biophys. Res. Comm., 2., $366(1960)$.

8. Cotter, R.I., P. McPhie and W.B. Gratzer, Nature, 216, 864 (1967).

9. Blake, A. and A. R. Peacocke, Nature, 208, 1319 (1965).

10. McPhie, P. and W. B. Gratzer, Biochem, 5, 1310, (1966).

11. Santer, M. Science, 141, 1049 (1963).

12. McPhie, P., J. Hounsell and W. B. Gratzer, Biochem, 5, 988 (1966).

13. Gould, H. Biochem, 2, 1103 (1966).

14. Eickenberry, E. F., T. A. Bickle, R. R. Traut and C. A. Price Eur. I. Biochem. 12 (1970).

15. Boyle, S. M. and Cohen, P.. S., Bacteriol Proc., 69, 147 (1969).

16. Bishop, O. H. L., J. R. Claybrook and S. Spiegelman, J. Mol. Biol., 26, 373 (1967).

17. Hartman, K. A., J. Amaya, E. M. Schachter, Science (1970).

18. Teraoka, H., I. Mol. Biol., 48, 511 (1970).

19. Spencer, M., W. J. Pigram and J. Littlechild, Biochem., Biophys., Acta, 179,348 (1969). 


\section{APPENDIX}

It is well known that monovalent cations, in cooperation with divalent cations, are important in the association and function of ribosomes ( $1, p .31)$. I thought it interesting to ask whether there are any changes in the fragment pattern of the mild hydrolysis for the 3 as ribosomal subunit as a function of the potassium ion concentration.

E. coli D10 $30 S$ ribosomes, obtained and concentrated as described in section II of this work, were digested in $0.005 \mathrm{M} \mathrm{KCl}, 0.005 \mathrm{M}$ $\mathrm{Mg}$ (Acetate $)_{2}$ and $0.005 \mathrm{M}$ Tris-Cl $(\mathrm{pH}=7.4)$, using $0.1-0.4 \mu \mathrm{g} / \mathrm{ml}$ of pRNase. The electrophoretic analysis of the RNA products showed a prominent band ( $\left.30^{\prime}\right)$ which reached maximum height toward the end of the first stage of hydrolysis (figure 1 of appendix):

The products from $30 \mathrm{~S}$ subunits hydrolyzed in $0.06 \mathrm{M} \mathrm{KCl}$, $0.001 \mathrm{M} \mathrm{Mg}$ (Acetate) 2 and $0.005 \mathrm{M}$ Tris-Cl ( $\mathrm{pH}=7.4)$ were analyzed in a $3.75 \%$ polyacrylamide gel after stopping the reaction with redistilled phenol and $0.1 \%$ SDS. The $2600 \mathrm{~A}$ - absorbance pattern is shown in figure 2 of this appendix. Outstanding features of this pattern are a) the evident accumulation of a least three different fragments, and b) the appearance of band $30 \mathrm{~A}^{\prime}$ which is absent from the other ribosomal fragment patterns.

It has been shown in section III of the thesis that mild hydrolysis of $30 \mathrm{~S}$ ribosomes in the absence of of $\mathrm{K}^{+}$yields fragments which do not accumulate. The preliminary data presented in this appendix argue that significant changes are introduced in the fragment pattern of the 30 subunit by varying the concentration of $\mathrm{KCl}$. An immediate conclusion 
is that perhaps the ribosome undergoes conformational transitions, and even exposes different sites to the RNase, at the measure that $\mathrm{K}^{+}$ is being added or subtracted. It has been suggested that a particular concentration of monovalent cations, such as $\mathrm{K}^{+}$and $\mathrm{NH}^{+}{ }_{4}$ may be responsible for the conformation adopted by the 50S subunit (18). A possible explanation of this phenomenon could be found in the ability of monovalent cations to exchange with the divalent cations that cross-link the RNA chain. 


\section{Appendix}

Figure 1

Fragment pattern of 30 s ribosomal subunits digested in 0.005 Molar $\mathrm{KCl}$. Deproteinization carried out with $0.2 \%$ SDS and RNA fragments analyzed in a 3\% polyacrylamide gel. Input ribosomes gave a single band in the position of the 16s RNA.

\section{Appendix}

Figure 2

Fragment pattern of $30 \mathrm{~S}$ subunits digested in $0.06 \mathrm{M} \mathrm{KCl}$. The RNA was recovered by the phenol method, and products. analyszed in a $3.75 \%$ polyacrylamide gel. Input ribosomes gave a single band in the position of the 16S RNA. 


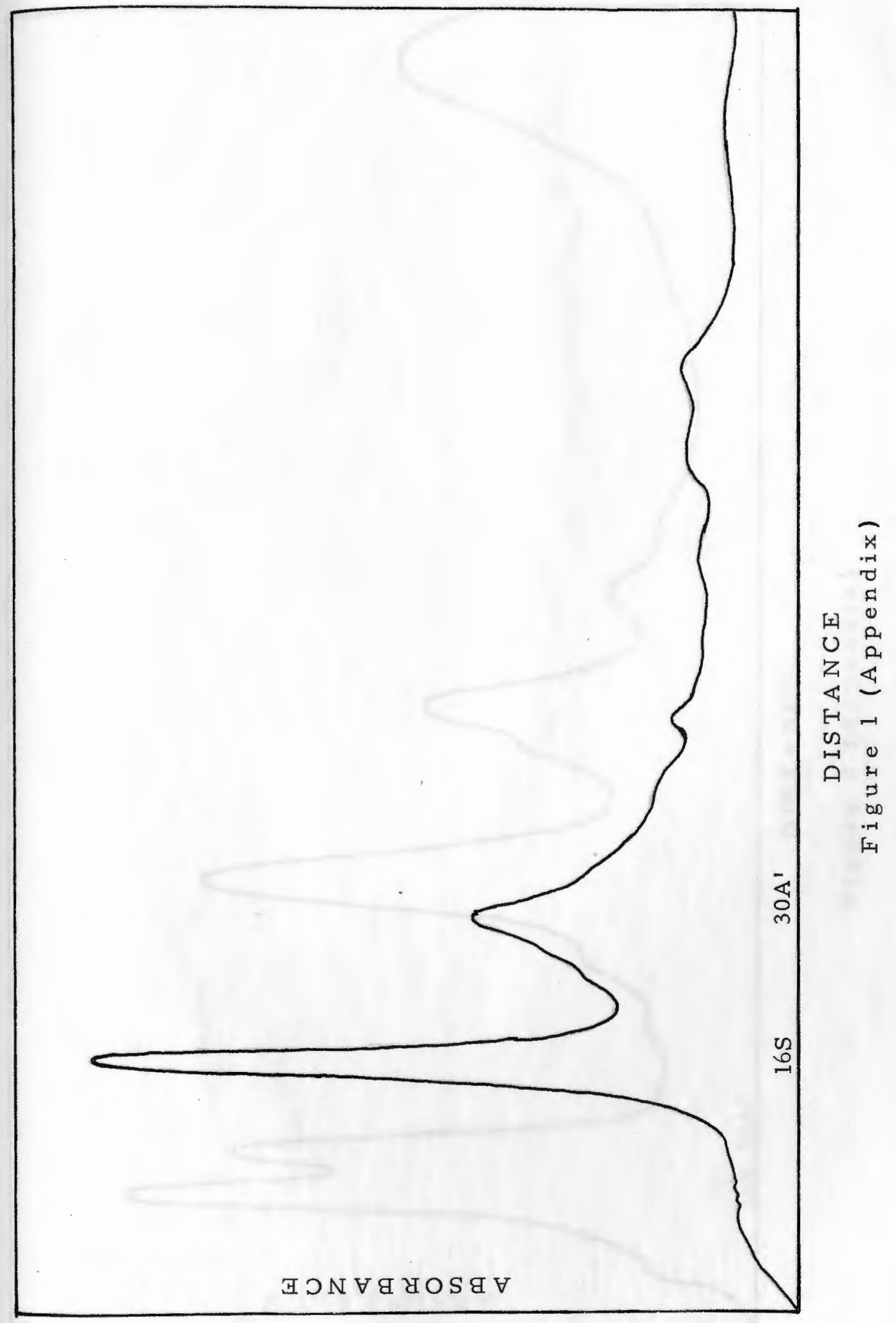




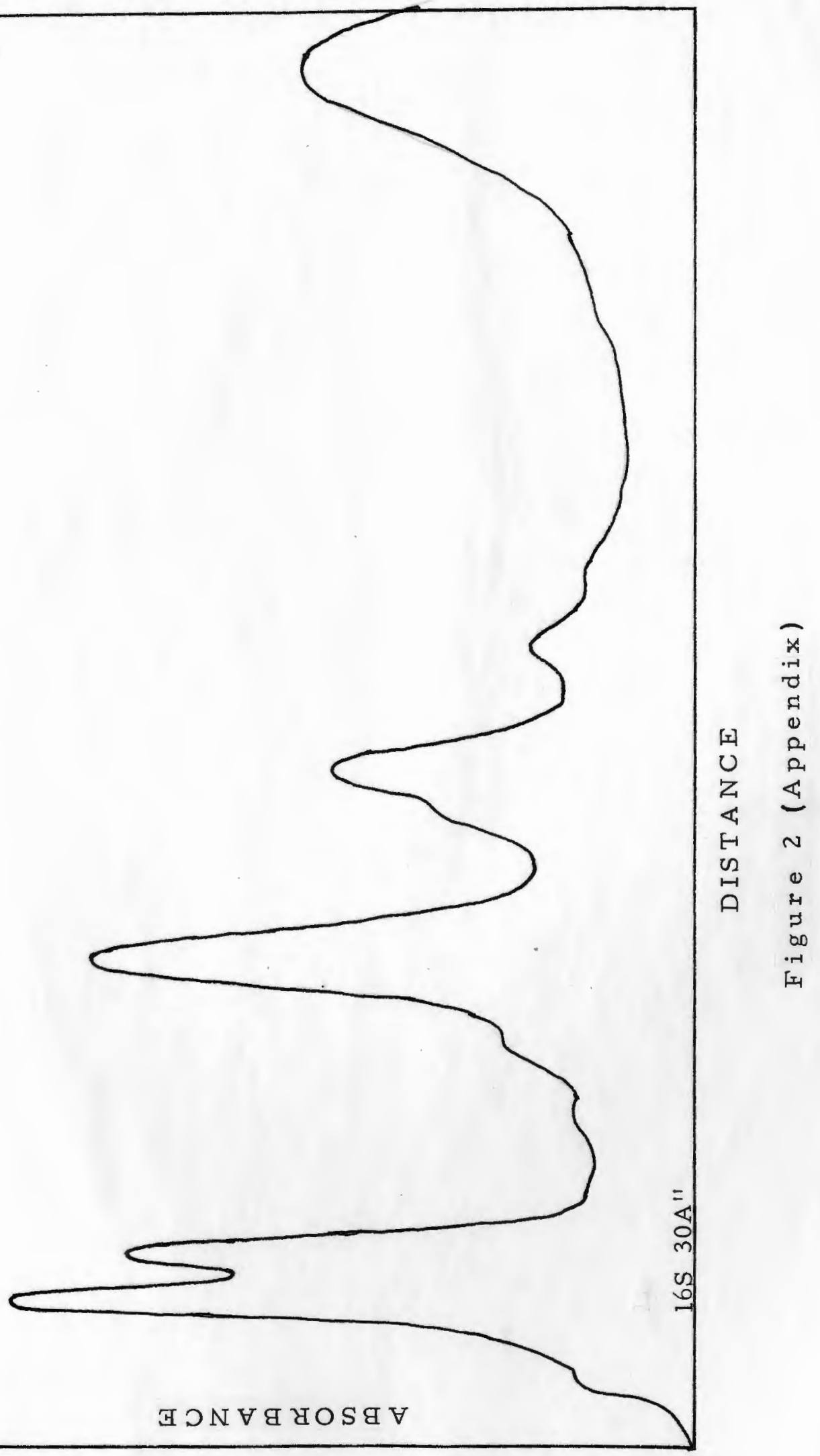

